\title{
High resveratrol or quercetin concentrations reduce the oscillation index of frozen goat semen
}

\author{
[Altas concentrações de resveratrol ou quercetina reduzem o índice de oscilação \\ do sêmen congelado caprino] \\ E.C.B. Silva ${ }^{1}$, L.C.P. Arruda ${ }^{1}$, S.V. Silva ${ }^{2}$, H.M. Souza ${ }^{1}$, M.M.P. Guerra ${ }^{1}$ \\ ${ }^{1}$ Universidade Federal Rural de Pernambuco - Recife, PE \\ ${ }^{2}$ Universidade Federal da Paraíba - João Pessoa, PR
}

\begin{abstract}
The aim of this study was to evaluate the effect of different concentrations of trans-resveratrol or quercetin on the ability of goat sperm to withstand being frozen. Six pools of semen obtained from six male goats were processed with different concentrations of resveratrol or quercetin (Experiment 1: 0, 15, $25,50,75$ or $100 \mu \mathrm{M}$ resveratrol; Experiment 2: 0, 15, 25, 50, 75 or $100 \mu \mathrm{M}$ quercetin) and frozen. After thawing, the semen was evaluated for sperm kinematics, plasma membrane and acrosome integrity, morphology and oxidative stress following 0 and $1 \mathrm{~h}$ of incubation. Immediately after thawing (0h), wobble (oscillation index) in the groups treated with $100 \mu \mathrm{M}$ of quercetin or resveratrol was lower $(\mathrm{P}<0.05)$ than in those treated with 0 and $25 \mu \mathrm{M}$ resveratrol and $0 \mu \mathrm{M}$ quercetin, respectively. After $1 \mathrm{~h}$ of incubation, the total motility in treatments with 15,50 and $75 \mu \mathrm{M}$ quercetin, as well as the plasma membrane integrity in all quercetin concentrations were lower $(\mathrm{P}<0.05)$ than at $0 \mathrm{~h}$. In opposition, the linearity of semen samples treated with $100 \mu \mathrm{M}$ quercetin and the straightness of those treated with 75 and $100 \mu \mathrm{M}$ quercetin were lower $(\mathrm{P}<0.05)$ at $0 \mathrm{~h}$ than at $1 \mathrm{~h}$ after thawing. Thus, it can be concluded that resveratrol and quercetin at high concentrations $(100 \mu \mathrm{M})$ transiently reduce the wobble of goat sperm submitted to frozen storage, and that quercetin $(75$ and $100 \mu \mathrm{M})$ increases the linearity and straightness over time, which can be favorable for fertility.
\end{abstract}

Keywords: antioxidant, flavonoid, no flavonoid, oxidative stress, semen freezing

\section{RESUMO}

O objetivo deste estudo foi avaliar o efeito de diferentes concentrações de transresveratrol ou quercetina sobre a capacidade dos espermatozoides caprinos de resistirem à congelação. Seis pools de sêmen, obtidos de seis reprodutores caprinos, foram processados com diferentes concentrações de resveratrol ou quercetina (Experimento 1: 0, 15, 25, 50, 75 ou 100 $\mu \mathrm{M}$ de resveratrol; Experimento 2: 0, 15, 25, 50, 75 ou $100 \mu \mathrm{M}$ de quercetina) e congelados. Após o descongelamento, o sêmen foi avaliado quanto à cinética espermática, à integridade das membranas plasmática e acrossomal, à morfologia e ao estresse oxidativo nos tempos zero e uma hora de incubação. Imediatamente após a descongelação (zero hora), o wobble (índice de oscilação) nos grupos tratados com $100 \mu M$ de quercetina ou de resveratrol foi menor $(P<0,05)$ do que nos tratados com 0 e $25 \mu M$ de resveratrol e com $0 \mu M$ de quercetina, respectivamente. Após uma hora de incubação, a motilidade total dos tratamentos com 15, 50 e 75 $\mu M$ de quercetina, assim como a integridade de membrana plasmática em todas as concentrações de quercetina, foi menor $(P<0,05)$ do que à zero hora. Em oposição, a linearidade das amostras de sêmen tratadas com $100 \mu M$ de quercetina e a retilinearidade daquelas tratadas com $75 \mu \mathrm{M}$ e $100 \mu \mathrm{M}$ de quercetina foram menores $(P<0,05)$ à zero hora do que à uma hora após descongelação. Assim, pode-se concluir que o resveratrol e a quercetina, em concentrações elevadas $(100 \mu \mathrm{M})$, reduzem, transitoriamente, o índice de oscilação de espermatozoides caprinos submetidos à congelação e que a quercetina (75 e 100uM) aumenta a linearidade e a retilinearidade ao longo do tempo, o que pode ser favorável à fertilidade.

Palavras-chaves: antioxidante, flavonoide, não flavonoide, estresse oxidativo, congelação de sêmen

Recebido em 12 de agosto de 2015

Aceito em 18 de fevereiro de 2016

E-mail: silva.ecb@gmail.com 


\section{INTRODUCTION}

Although the artificial insemination (AI) using cryopreserved semen allows for the intensification of production systems and the genetic improvement of goat herds, semen cryopreservation, and especially the process of freezing, causes structural and functional sperm damage that impairs fertility (Leboeuf et al., 2000). Among the factors responsible for generating injury during cryopreservation is oxidative stress (Zribi et al., 2012).

An imbalance between the production of reactive oxygen species (ROS) and the antioxidant defense systems present in the semen can compromise sperm physiology and viability (Ranawat et al., 2013). Therefore, the use of antioxidant therapies during semen processing aims to combat oxidative damage (Agarwal et al., 2005).

Trans-resveratrol and quercetin have gained attention for their high antioxidant potential (Sarlós et al., 2002; Zribi et al., 2012). Transresveratrol is a non-flavonoid phenolic compound that belongs to the stilbenes family (Planas et al., 2011), whereas quercetin is an aglycone flavonoid of the flavonols subclass (Kelly, 2011). Both phytochemical agents are found in plants and their derived products (Kelly, 2011; Planas et al., 2011).

Despite trans-resveratrol and quercetin being described as potent antioxidants, its effects on semen are inconclusive (Silva et al., 2012). Based on this information and on the need to develop a suitable method to freeze goat semen, the aim of this study was to evaluate the effect of different concentrations of trans-resveratrol or quercetin on the cryopreservation of goat sperm.

\section{MATERIALS AND METHODS}

Unless specified in the text, all reagents used in this study were obtained from the SigmaAldrich $^{\circledR}$ company (St Louis, MO, USA).

This study was approved by the Ethics Committee for Animal Experimentation of the Universidade Federal Rural de Pernambuco (UFRPE - Brazil), under process number CEEUA/UFRPE 014/2012. Six mature and fertile male goats (three Saanen, two Toggenburg and one British Alpine) from one to four years old were used. The animals were raised at
UFRPE, Pernambuco, Brazil (08 $08^{\circ}$ ' 14' ' S; $34^{\circ}$ 52 ' 52 ' W), fed with hay twice a day and $400 \mathrm{~g}$ commercial chow, and mineral salt and water ad libitum.

The semen collections occurred between May and August 2013, and were performed by artificial vagina, with a female in heat as a dummy, at $48 \mathrm{~h}$ intervals, totaling 36 ejaculates per experiment (six per buck). Fresh semen samples were examined using phase-contrast microscopy (Olympus, Tokyo, Japan) to determine mass movement (0-5), motility and vigor $(0-100 \%$ and $0-5$, respectively; 100x), sperm concentration in a Neubauer chamber (400x) and sperm pathologies in a moist chamber (1000x). Approved ejaculates (mass movement $\geq$ 3 , motility $\geq 70 \%$, vigor $\geq 3$, concentration $\geq 2 x$ $10^{9} \mathrm{sperm} / \mathrm{mL}$, and total sperm pathologies $\leq$ $20 \%)$ were pooled, totaling six pools $(n=6)$ per experiment.

Each of the six goat semen pools were diluted $(1: 9 ; \mathrm{v}: \mathrm{v})$ in a Tris solution [3.605g Trishydroxymethyl aminomethane (T1378), 2.024g citric acid (C2404), 1.488g fructose (F3510) and $100 \mathrm{~mL}$ Milli-Q water, $\mathrm{pH}$ 6.8] and centrifuged (250x $\mathrm{g}$ for 10min) twice to remove seminal plasma. Subsequently, semen samples were divided into six equal aliquots and diluted with a skim milk-based extender $[10 \mathrm{~g}$ skim milk powder, 194mg D-(+)-glucose (G6152), 100mL Milli-Q water, 7\% glycerol (G2025), $\mathrm{pH}$ 6.8] supplemented or without resveratrol or quercetin, according to experiments or experimental groups [Experiment 1: 0, 15, 25, 50, 75 or $100 \mu \mathrm{M}$ resveratrol (R5010); Experiment 2: 0, 15, 25, 50, 75 or $100 \mu \mathrm{M}$ quercetin (Q4951)]. The resveratrol and quercetin stock solutions $(10 \mathrm{mM})$ were prepared in DMSO (D4540) and stored at $-20^{\circ} \mathrm{C}$. Semen samples diluted to a final concentration of $200 \times 10^{6} \mathrm{sperm} / \mathrm{mL}$ were packed into $0.25 \mathrm{~mL}$ straws and frozen in an automated system (TK3000®, TK Tecnologia em congelação Ltd, Uberaba, Brazil), using a slow temperature curve that was specific for goats. The straws were immersed and stored in liquid nitrogen $\left(-196^{\circ} \mathrm{C}\right)$ until thawing.

At a minimum duration of $24 \mathrm{~h}$ of frozen storage, four straws per experimental group were thawed $\left(37^{\circ} \mathrm{C}\right.$ for $\left.30 \mathrm{~s}\right)$. The semen samples were incubated at $34^{\circ} \mathrm{C}$ and were analyzed at 0 and $1 \mathrm{~h}$ after thawing, as described below. This 
procedure was repeated six times for each experiment and experimental group $(n=6)$.

For sperm kinematics analysis, aliquots of semen were diluted $(1: 4 ; \mathrm{v}: \mathrm{v})$ in skim milk-based extender to reduce the sperm concentration. An aliquot of semen $(5 \mu \mathrm{L})$ was deposited onto a prewarmed slide $\left(37^{\circ} \mathrm{C}\right)$, covered with a cover slip and analyzed in a phase contrast microscope (100x; Nikon ${ }^{\mathrm{TM}}$ H5505, Eclipse 50i, Tokyo, Japan) attached to a video camera (Basler Vision TecnologieTM A312FC, Ahrensburg, Germany). Five non-consecutive fields were randomly selected per sample, and at least 2000 sperm were registered for analysis. The parameters evaluated using the Sperm Class Analyzer $\mathrm{SCA}^{\mathrm{TM}}$ software v. 5.1 (Microptics, SL, Barcelona, Spain) were total motility (TM), progressive motility (PM), linearity (LIN), straightness (STR) and wobble (WOB; oscillation index), expressed as percentage values (\%); curvilinear velocity (VCL), straight line velocity (VSL) and average path velocity (VAP), expressed as micrometers per second $(\mu \mathrm{m} / \mathrm{s})$; amplitude of lateral head displacement $(\mathrm{ALH})$, expressed as micrometers $(\mu \mathrm{m})$; and beat cross frequency $(\mathrm{BCF})$, expressed as hertz $(\mathrm{Hz})$.

The plasma membrane integrity was determined by a double staining method with carboxyfluorescein diacetate (CFDA; C5041) and propidium iodide (PI; P4170), according to Silva et al. (2012). 200 cells per slide were analyzed in an epifluorescence microscope (Carl Zeiss, Göttingen, Germany, 400x), using a DBP 485-520nm excitation filter and a DBP 580$630 \mathrm{~nm}$ emission filter. Sperm stained with green or red fluorescence were interpreted as having intact or damaged plasma membranes, respectively.

To determine the acrosome integrity, a fluorescein isothiocyanate probe conjugated with peanut agglutinin (FITC-PNA; L7381) was used (Silva et al., 2012). A total number of 200 spermatozoa per slide were examined using a LP $515 \mathrm{~nm}$ emission filter and a BP 450-490 nm excitation filter in an epifluorescence microscope (Carl Zeiss, Göttingen, Germany, 1000x). The gametes were classified as having an intact acrosome when stained with fluorescent green or as having a reacted acrosome when the fluorescent green was either present only in the equatorial region or absent from the entire head of the cell.
The sperm morphology was analyzed by the moist chamber method (Oliveira et al., 2013). 200 cells were analyzed per slide using a phasecontrast microscope (Olympus, Tokyo, Japan, 1000x), and were classified as morphologically normal or abnormal.

The study of oxidative stress on goat sperm was conducted by the nitroblue tetrazolium test (NBT, N6639), according Saleh and Agarwal (2002). 100 sperm were examined per slide in a phase contrast microscope (Olympus, Tokyo, Japan, 1000x). The gametes were classified as presenting oxidative stress when formazan was found deposited in the head or midpiece or as not presenting oxidative stress when there was no formazan deposit.

The results of this study were expressed as means and standard deviations (mean \pm SD). Before statistical analyses, all the percentage data were arcsine transformed. Comparisons between experimental groups and times were made using one-way ANOVA followed by a multiple comparison Tukey-Kramer test (INSTAT for Windows, version 3.01). For all analyses, values were considered significant at $\mathrm{P}<0.05$.

\section{RESULTS}

Kinematic analyses of goat sperm, frozen with resveratrol or quercetin at different concentrations $(0,15,25,50,75$ or $100 \mu \mathrm{M})$ found no significant differences $(\mathrm{P}>0.05)$ between the experimental groups for most kinematic parameters (TM, LIN, STR VCL, VSL, VAP, ALH and BCF) analyzed at time 0 and $1 \mathrm{~h}$ after thawing, in both experiments (Tab. 1 and 2). However, it was found that the oscillation ratio (WOB) of gametes that were cryopreserved with $100 \mu \mathrm{M}$ resveratrol (Experiment 1, Tab. 1) or quercetin (Experiment 2, Tab. 2) were lower $(\mathrm{P}<0.05)$ than those frozen with $0 \mu \mathrm{M}$ and $25 \mu \mathrm{M}$ resveratrol or $0 \mu \mathrm{M}$ quercetin, respectively.

After comparing the treatment groups over incubation time, TM was higher $(\mathrm{P}<0.05)$ at $0 \mathrm{~h}$ than at $1 \mathrm{~h}$ in goat semen samples added of 15,50 and $75 \mu \mathrm{M}$ quercetin. In contrast, LIN in the group treated with $100 \mu \mathrm{M}$ quercetin and STR in the groups 75 and $100 \mu \mathrm{M}$ quercetin were lower $(\mathrm{P}<005)$ at $0 \mathrm{~h}$ than at $1 \mathrm{~h}$ after thaw (Tab. 2). 
Table 1. Kinematic parameters (Means \pm SD) of goat semen samples frozen in a skim milk-based extender $(7 \%$ glycerol) with different concentrations of resveratrol $(0,15,25,5075$ and $100 \mu \mathrm{M})$ evaluated at 0 and $1 \mathrm{~h}$ after thawing

\begin{tabular}{|c|c|c|c|c|c|c|}
\hline & R0 & $\mathrm{R} 15$ & R25 & R50 & R75 & R100 \\
\hline \multicolumn{7}{|l|}{ Time $0 \mathrm{~h}$} \\
\hline TM (\%) & $54.3 \pm 19.3$ & $50.1 \pm 21.0$ & $47.3 \pm 18.5$ & $44.8 \pm 15.7$ & $49.7 \pm 9.6$ & $57.8 \pm 10.8$ \\
\hline VCL $(\mu \mathrm{m} / \mathrm{s})$ & $67.5 \pm 5.9$ & $72.1 \pm 11.7$ & $75.5 \pm 7.7$ & $68.3 \pm 6.5$ & $67.6 \pm 12.4$ & $70.5 \pm 7.7$ \\
\hline $\mathrm{VSL}(\mu \mathrm{m} / \mathrm{s})$ & $37.9 \pm 4.9$ & $40.0 \pm 8.9$ & $41.7 \pm 4.7$ & $35.0 \pm 6.8$ & $35.4 \pm 7.2$ & $34.4 \pm 5.5$ \\
\hline $\mathrm{VAP}(\mu \mathrm{m} / \mathrm{s})$ & $47.3 \pm 5.0$ & $50.1 \pm 10.1$ & $53.0 \pm 5.2$ & $45.0 \pm 6.2$ & $45.0 \pm 10.2$ & $45.1 \pm 6.3$ \\
\hline WOB (\%) & $70.0 \pm 3.6 \mathrm{a}$ & $69.1 \pm 3.6 \mathrm{ab}$ & $70.2 \pm 2.8 \mathrm{a}$ & $65.8 \pm 3.9 \mathrm{ab}$ & $66.2 \pm 2.7 \mathrm{ab}$ & $63.7 \pm 2.8 b$ \\
\hline $\mathrm{ALH}(\mu \mathrm{m})$ & $2.8 \pm 0.3$ & $2.9 \pm 0.2$ & $3.1 \pm 0.4$ & $3.1 \pm 0.2$ & $2.9 \pm 0.2$ & $3.2 \pm 0.2$ \\
\hline $\mathrm{BCF}(\mathrm{Hz})$ & $11.5 \pm 1.3$ & $11.9 \pm 1.5$ & $11.6 \pm 0.8$ & $12.2 \pm 0.8$ & $12.3 \pm 0.8$ & $12.5 \pm 1.2$ \\
\hline \multicolumn{7}{|l|}{ Time $1 \mathrm{~h}$} \\
\hline TM (\%) & $37.0 \pm 14.8$ & $41.7 \pm 13.0$ & $39.5 \pm 14.0$ & $33.1 \pm 11.7$ & $33.5 \pm 14.5$ & $35.0 \pm 13.5$ \\
\hline PM (\%) & $11.7 \pm 3.5$ & $14.7 \pm 7.1$ & $14.0 \pm 8.5$ & $12.5 \pm 7.0$ & $11.5 \pm 5.9$ & $12.4 \pm 8.3$ \\
\hline LIN (\%) & $52.6 \pm 3.9$ & $53.4 \pm 3.7$ & $52.3 \pm 3.9$ & $52.6 \pm 1.5$ & $52.4 \pm 3.8$ & $51.8 \pm 3.7$ \\
\hline STR (\%) & $80.3 \pm 3.6$ & $79.5 \pm 2.1$ & $80.1 \pm 4.0$ & $82.0 \pm 1.5$ & $80.5 \pm 3.7$ & $80.3 \pm 2.2$ \\
\hline WOB (\%) & $65.5 \pm 3.0$ & $67.2 \pm 3.5$ & $65.3 \pm 2.0$ & $64.2 \pm 1.0$ & $65.0 \pm 2.4$ & $64.4 \pm 3.3$ \\
\hline $\mathrm{ALH}(\mu \mathrm{m})$ & $2.9 \pm 0.2$ & $2.9 \pm 0.2$ & $2.9 \pm 0.1$ & $3.0 \pm 0.2$ & $3.0 \pm 0.4$ & $3.0 \pm 0.3$ \\
\hline $\mathrm{BCF}(\mathrm{Hz})$ & $13.1 \pm 1.4$ & $12.7 \pm 0.8$ & $12.8 \pm 0.9$ & $13.7 \pm 0.6$ & $13.3 \pm 0.9$ & $13.3 \pm 0.5$ \\
\hline
\end{tabular}

Different letters in the same line denote significant differences between groups $(\mathrm{P}<0.05)$. TM: total motility; PM: progressive motility; VCL: curvilinear velocity; VSL: straight linear velocity; VAP: average path velocity; LIN: linearity; STR: straightness; WOB: wobble; ALH: amplitude of lateral movement of sperm head; BCF: beat cross frequency.

Table 2. Kinematic parameters (Means \pm SD) of goat semen samples frozen in a skim milk-based extender (7\% glycerol) with different concentrations of quercetin $(0,15,25,5075$ and $100 \mu \mathrm{M})$ evaluated at 0 and $1 \mathrm{~h}$ after thawing

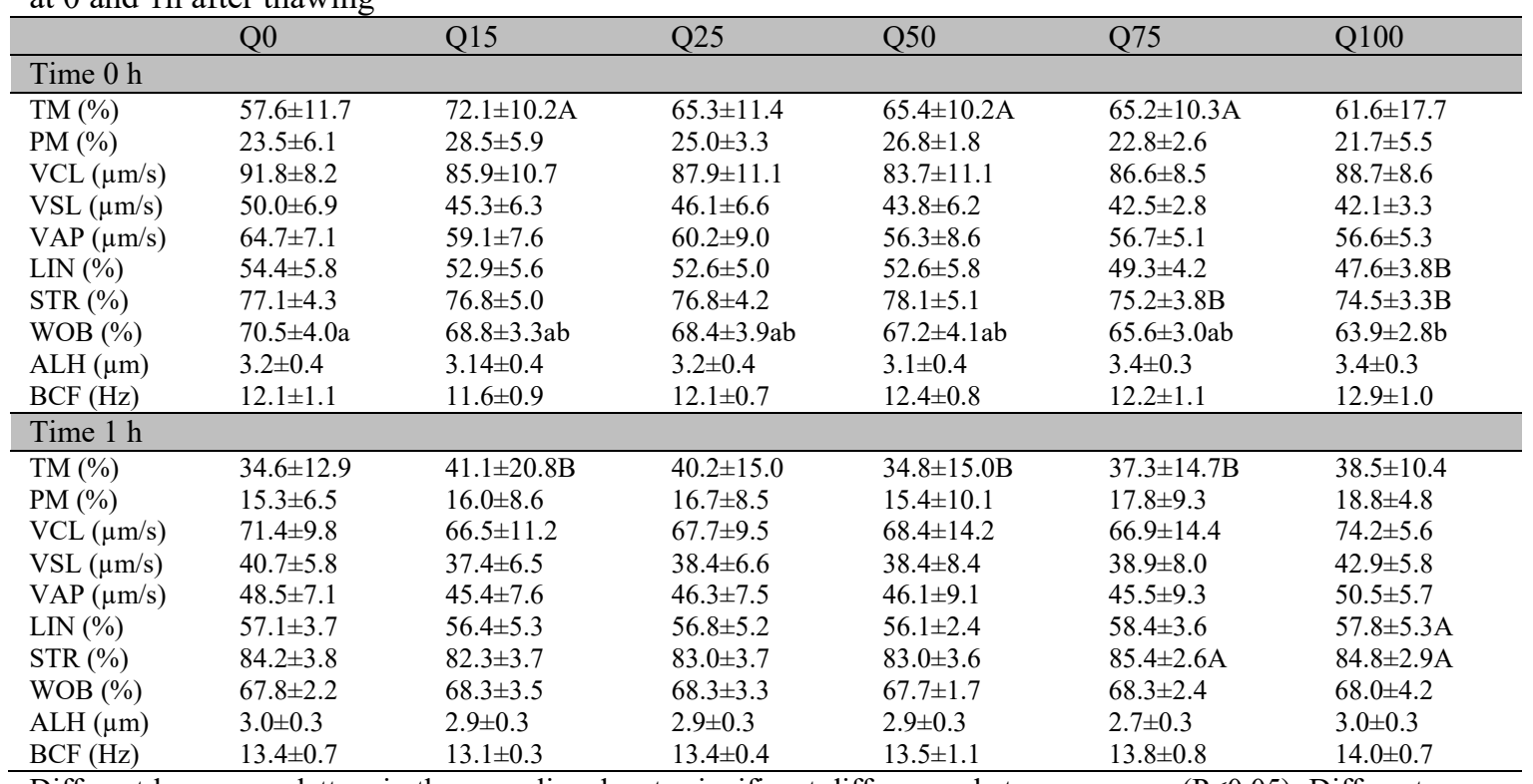

Different lower case letters in the same line denote significant differences between groups $(\mathrm{P}<0.05)$. Different upper case letters in the same column denote significant differences between times in the same group ( $<<0.05)$. TM: total motility; PM: progressive motility; VCL: curvilinear velocity; VSL: straight linear velocity; VAP: average path velocity; LIN: linearity; STR: straightness; WOB: wobble; ALH: amplitude of lateral movement of sperm head; BCF: beat cross frequency. 
Similarly, significant differences were not observed $(\mathrm{P}>0.05)$ for plasma membrane integrity, acrosome integrity, percentage of morphologically normal sperm and oxidative stress between the experimental groups in the evaluations conducted at 0 and $1 \mathrm{~h}$ after thawing
(Tab. 3 and 4). However, after comparing the groups over incubation times, the values of plasma membrane integrity of all groups treated with quercetin were lower $(\mathrm{P}<0.05)$ after $1 \mathrm{~h}$ of incubation than at $\mathrm{Oh}$ (Tab. 4).

Table 3. Plasma membrane and acrosome integrity, normal morphology and negative oxidative stress (Means \pm SD) of goat semen samples frozen in a skim milk-based extender (7\% glycerol) with different concentrations of resveratrol $(0,15,25,5075$ and $100 \mu \mathrm{M})$ evaluated at 0 and $1 \mathrm{~h}$ after thawing

\begin{tabular}{lllllll}
\hline & R0 & R15 & R25 & R50 & R75 & R100 \\
\hline Time 0h & & & & & & \\
\hline iPM (\%) & $34.7 \pm 12.2$ & $39.5 \pm 10.4$ & $37.2 \pm 7.6$ & $39.4 \pm 3.6$ & $38.5 \pm 10.6$ & $32.8 \pm 10.3$ \\
iAC (\%) & $44.3 \pm 9.2$ & $49.8 \pm 7.5$ & $51.3 \pm 3.1$ & $49.6 \pm 7.0$ & $51.6 \pm 8.7$ & $47.9 \pm 11.2$ \\
nMOR (\%) & $88.5 \pm 5.9$ & $87.9 \pm 2.9$ & $88.1 \pm 2.3$ & $85.2 \pm 3.7$ & $86.2 \pm 2.0$ & $85.9 \pm 2.6$ \\
-OE (\%) & $73.5 \pm 6.7$ & $74.5 \pm 2.1$ & $76.5 \pm 2.1$ & $76.2 \pm 6.7$ & $72.7 \pm 6.5$ & $77.8 \pm 5.7$ \\
\hline Time 1h & & & & & & \\
\hline iPM (\%) & $18.2 \pm 6.2$ & $20.4 \pm 7.0$ & $19.8 \pm 8.8$ & $18.4 \pm 4.6$ & $22.6 \pm 7.2$ & $23.3 \pm 4.2$ \\
iAC (\%) & $43.5 \pm 19.0$ & $46.0 \pm 10.4$ & $43.7 \pm 5.6$ & $41.8 \pm 5.6$ & $46.1 \pm 6.8$ & $49.3 \pm 6.6$ \\
nMOR (\%) & $87.6 \pm 2.7$ & $87.7 \pm 3.6$ & $86.9 \pm 4.9$ & $86.8 \pm 4.1$ & $84.6 \pm 8.4$ & $86.1 \pm 4.2$ \\
-OE (\%) & $72.7 \pm 5.3$ & $72.3 \pm 5.6$ & $73.5 \pm 6.0$ & $72.5 \pm 4.3$ & $69.8 \pm 2.0$ & $71.5 \pm 7.2$ \\
\hline
\end{tabular}

iPM: plasma membrane integrity; iAC: acrosome integrity; nMOR: normal morphology; -OS: negative oxidative stress.

Table 4. Plasma membrane and acrosome integrity, normal morphology and negative oxidative stress (Means $\pm \mathrm{SD}$ ) of goat semen samples frozen in a skim milk-based extender ( $7 \%$ glycerol), with different concentrations of quercetin $(0,15,25,5075$ and $100 \mu \mathrm{M})$, evaluated at 0 and $1 \mathrm{~h}$ after thawing

\begin{tabular}{lllllll} 
& Q0 & Q15 & Q25 & Q50 & Q75 & Q100 \\
\hline Time 0h & & & & & & \\
\hline iPM (\%) & $47.3 \pm 8.9 \mathrm{a}$ & $44.3 \pm 11.4 \mathrm{a}$ & $49.3 \pm 9.6 \mathrm{a}$ & $48.5 \pm 12.2 \mathrm{a}$ & $46.6 \pm 9.2 \mathrm{a}$ & $46.0 \pm 10.3 \mathrm{a}$ \\
iAC (\%) & $53.3 \pm 6.7$ & $56.9 \pm 9.3$ & $57.4 \pm 9.3$ & $56.6 \pm 9.57$ & $57.8 \pm 8.0$ & $58.2 \pm 9.0$ \\
nMOR (\%) & $90.4 \pm 5.1$ & $90.9 \pm 8.3$ & $91.7 \pm 5.0$ & $92.8 \pm 1.9$ & $91.7 \pm 5.9$ & $91.7 \pm 5.5$ \\
-OE (\%) & $73.8 \pm 2.7$ & $77.7 \pm 3.0$ & $79.5 \pm 3.7$ & $78.8 \pm 4.6$ & $77.5 \pm 5.2$ & $77.3 \pm 6.0$ \\
\hline Time 1h & & & & & & \\
\hline iPM (\%) & $23.5 \pm 7.1 \mathrm{~b}$ & $23.0 \pm 8.4 \mathrm{~b}$ & $25.8 \pm 6.8 \mathrm{~b}$ & $25.3 \pm 9.8 \mathrm{~b}$ & $24.6 \pm 8.9 \mathrm{~b}$ & $25.8 \pm 9.8 \mathrm{~b}$ \\
iAC (\%) & $49.4 \pm 10.2$ & $50.6 \pm 6.9$ & $48.8 \pm 6.2$ & $51.2 \pm 7.5$ & $45.0 \pm 5.3$ & $47.9 \pm 4.4$ \\
nMOR (\%) & $91.0 \pm 5.2$ & $92.8 \pm 1.3$ & $94.8 \pm 1.1$ & $94.1 \pm 1.3$ & $94.8 \pm 1.6$ & $95.4 \pm 2.0$ \\
-OE (\%) & $70.7 \pm 4.4$ & $72.5 \pm 6.9$ & $75.0 \pm 8.3$ & $71.7 \pm 5.6$ & $71.2 \pm 7.0$ & $70.5 \pm 6.7$ \\
\hline
\end{tabular}

Different letters in the same column denote significant differences between times in the same group ( $\mathrm{P}<0.05)$. iPM: plasma membrane integrity; iAC: acrosome integrity; nMOR: normal morphology; -OS: negative oxidative stress.

\section{DISCUSSION}

The inhibitory effect of resveratrol (MartínHidalgo et al., 2013) and quercetin (Johinke et al., 2014) on the sperm Kinematic of different species has been reported, particularly when used at high concentrations. In this study, with the exception of the oscillation index (WOB) at time $0 \mathrm{~h}$, treating goat semen with different concentrations $(0,15,25,50,75$ and $100 \mu \mathrm{M})$ of trans-resveratrol or quercetin did not alter the sperm kinematics.

It is noteworthy that the oscillation index (WOB) is described as being inversely proportional to
STR (Perumal et al., 2014), a parameter that is positively correlated with the fertility rate (Matos et al., 2008). In this context, a high oscillation index (WOB) is associated with the elevation of curvilinear motion, in opposition to progressive movement, which explains the decrease in the quality and fertility of frozen semen (Silva et al., 2011). Thus, the reduction of WOB observed in this study may represent a favorable event for the maintenance of goat sperm submitted to freezing, possibly without affecting the sperm capacitation, because the effect was transitory.

The differences between studies released with the use of resveratrol and quercetin polyphenols 
have been attributed to the dose and differences between species (Moretti et al., 2012; MartínHidalgo et al., 2013). According to the species, enzymes that are directly or indirectly linked to sperm motility maintenance, such as $\mathrm{Ca}^{2+}$ ATPase (Nass-Arden and Breitbart, 1990), F0F1ATPase (Zheng and Ramirez, 2000) and cyclooxygenase (COX) (Kowalska et al., 2011), are inhibited to varying degrees.

In this study, the parameters of plasma membrane and acrosomal integrity, sperm morphology and oxidative stress were not altered in the presence of resveratrol or quercetin. In contrast, the addition of resveratrol (Sarlós et al., 2002) or quercetin (Moretti et al., 2012; Johinke et al., 2014) to semen of different species is associated with the prevention of oxidative damage. However, in most studies, the reduction of lipid peroxidation promoted by these phenolic compounds was observed after the induction of oxidation. Therefore, it is likely that the protective effect of these antioxidants becomes visible only in situations of extreme stress, which does not necessarily reflect the physiological conditions to which the semen is exposed.

Sperm kinematics (Mortimer, 2000) and the plasma membrane and acrosomal integrity (Silva and Gadella, 2006) are critical for sperm fertility. Thus, according to the results of this study, the use of resveratrol or quercetin during the goat semen freezing process does not appear to be justified because they do not increase these sperm parameters.

Despite the above observations, no deleterious effects were observed on gametes, and the oscillation index (WOB) was reduced temporarily after treatment with $100 \mu \mathrm{M}$ resveratrol or quercetin, as well as LIN and STR being greater after $1 \mathrm{~h}$ of incubation with quercetin $(75$ and $100 \mu \mathrm{M})$. It is possible that after the induction of oxidation, as has been described in other studies (Sarlós et al., 2002; Moretti et al. 2012), these polyphenols may manifest a protective action on goat semen. Moreover, based on the transitory inhibitory action observed, it is possible that these antioxidants do not compromise the manifestation of the events necessary for fertilization, such as capacitation.
Due to the species-specific variability of resveratrol and quercetin action, as well as the absence of previous studies using these agents on goat sperm, further investigations are necessary. The action mechanisms of these antioxidants on goat sperm should be clarified and related to enzyme activity and the maintenance of sperm physiology. Additionally, in vivo studies are needed to determine whether the therapy with polyphenols resveratrol and quercetin is of interest to reproductive practices in veterinary medicine, where AI is the most widespread reproductive technique.

\section{CONCLUSION}

In conclusion, resveratrol or quercetin at high concentrations $(100 \mu \mathrm{M})$ transiently reduce the oscillation index of goat semen submitted to frozen storage, and quercetin (75 and $100 \mu \mathrm{M})$ increase the linearity and straightness over time, which can be favorable for fertility.

\section{ACKNOWLEDGEMENT}

The authors are grateful to FACEPE, CNPq, CAPES, and RENORBIO.

\section{REFERENCES}

AGARWAL, A.; PRABAKARAN, S.A.; SAID, T.M. Prevention of oxidative stress injury to sperm. J. Androl., v.26, p.654-660, 2005.

JOHINKE, D.; GRAAF, S.P.; BATHGATE, R. Quercetin reduces the in vitro production of $\mathrm{H}_{2} \mathrm{O}_{2}$ during chilled storage of rabbit spermatozoa. Anim. Reprod. Sci., v.151, p.208219, 2014.

KELLY, G.S. Quercetin. Altern. Med. Rev., v.16, p.172-194, 2011.

KOWALSKA, A.; KOWALSKI, R.K.; ZAKĘŚ, $Z$. The effect of selective cyclooxygenase (COX) inhibitors on japanese medaka (Oryzias latipes) reproduction parameters. World Acad. Sci. Eng. Technol., v.53, p.19-23, 2011.

LEBOEUF, B.; RESTALL, B.; SALAMON, S. Production and storage of goat semen for artificial insemination. Anim. Reprod. Sci., v.62, p.113-141, 2000. 
MARTÍN-HIDALGO, D.; LLERA, A.H.; HENNING, H. et al. The effect of resveratrol on the quality of extended boar semen during storage at $17^{\circ}$ C. J. Agric. Sci., v.5, p.231-242, 2013.

MATOS, D.L.; ARAÚJO, A.A.; ROBERTO, I.G. et al. Análise computarizada de espermatozóides: revisão de literatura (computerassisted sperm analysis (CASA): a review). Rev. Bras. Reprod. Anim., v.32, p.225-232, 2008.

MORETTI, E.; MAZZI, L.; TERZUOLI, G. et al. Effect of quercetin, rutin, naringenin and epicatechin on lipid peroxidation induced in human sperm. Reprod. Toxicol., v.34, p.651-657, 2012.

MORTIMER, S.T. CASA: practical aspects. $J$. Androl., v.21, p.515-524, 2000.

NASS-ARDEN, L.; BREITBART, H. Modulation of mammalian sperm motility by quercetin. Mol. Reprod. Devel., v.25, p.369-373, 1990.

OLIVEIRA, M.E.F.; TEIXEIRA, P.P.M.; VICENTE, W.R.R. Biotécnicas reprodutivas em ovinos e caprinos. São Paulo: MedVet, 2013. $330 \mathrm{p}$.

PERUMAL, P.; SRIVASTAVA, S.K.; GHOSH, S.K. et al. Computer-assisted sperm analysis of freezable and nonfreezable Mithun (Bos frontalis) semen. J. Anim., v.2014, p.1-6, 2014.

PLANAS, J.M.; COLOM, H.; JUAN, M.E. Resveratrol: a polyphenol with multiple effects. Recent Adv. Pharmacol. Sci., v.2, p.101-120, 2011.
RANAWAT, P.; KAUSHIK, G.; SAIKIA, U.N. et al. Quercetin impairs the reproductive potential of male mice. Andrologia, v.45, p.5665, 2013.

SALEH, R.A.; AGARWAL, A. Oxidative stress and male infertility: from research bench to clinical practice. J. Androl., v.23, p.737-752, 2002.

SARLÓS, P.; MOLNÁR, A.; KÓKAI, M. et al. Comparative evaluation of the effect of antioxidants in the conservation of ram semen. Acta Vet. Hung., v.50, p.235-45, 2002.

SILVA, E.C.B.; CAJUEIRO, J.F.P.; SILVA, S.V. et al. Effect of antioxidants resveratrol and quercetin on in vitro evaluation of frozen ram sperm. Theriogenology, v.77, p.1722-1726, 2012.

SILVA, P.F.N.; GADELLA, B.M. Detection of damage in mammalian sperm cells. Theriogenology, v.65, p.958-978, 2006.

SILVA, S.V.; SOARES, A.T.; BATISTA, A.M. et al. In vitro and in vivo evaluation of ram sperm frozen in tris egg-yolk and supplemented with superoxide dismutase and reduced glutathione. Reprod. Dom. Anim., v.46, p.874$881,2011$.

ZHENG, J.; RAMIREZ, V.D. Inhibition of mitochondrial proton F0F1-ATPase/ATP synthase by polyphenolic phytochemicals. $B r . J$. Pharmacol., v.130, p.1115-1123, 2000.

ZRIBI, N.; CHAKROUN, N.F.; ABDALLAH, F.B. et al. Effect of freezing-thawing process and quercetin on human sperm survival and DNA integrity. Cryobiology, v.65, p.326-331, 2012. 